\title{
Groundwater circulation relative to water quality and vegetation in an arid transitional zone linking oasis, desert and river
}

\author{
HUANG TianMing ${ }^{1,2}$, PANG ZhongHe ${ }^{1 *}$, CHEN YaNing ${ }^{2} \&$ KONG YanLong ${ }^{1}$ \\ ${ }^{1}$ Key Laboratory of Engineering Geomechanics, Institute of Geology and Geophysics, Chinese Academy of Sciences, Beijing 100029, China; \\ ${ }^{2}$ State Key Laboratory of Desert and Oasis Ecology, Xinjiang Institute of Ecology and Geography, Chinese Academy of Sciences, Urumqi 830011, China
}

Received November 16, 2012; accepted April 23, 2013; published online July 23, 2013

\begin{abstract}
In groundwater-dependent ecosystems, groundwater circulation controls the overall water quality and ecosystem dynamics. Groundwater and vegetation across a $30-\mathrm{km}$ groundwater transect linking oasis, desert and river in an extremely arid area were investigated with a series of soil profiles drilled into the unsaturated zone to understand groundwater circulation and its control on groundwater quality and surface vegetation in the extremely arid Lower Tarim River, NW China. Measurements have included water-table depth, water chemistry and water isotopes $\left({ }^{2} \mathrm{H},{ }^{18} \mathrm{O},{ }^{3} \mathrm{H}\right)$ for 15 water samples, soil moisture and chloride content for 11 soil profiles, and vegetation investigation. Results show that the groundwater in desert zone is characterized by slow recharge rate (pre-modern water), great water-table depth $(6.17-9.43 \mathrm{~m})$ and high salinity $(15.32-26.50 \mathrm{~g} / \mathrm{L})$, while that in oasis (uncultivated land) and riparian zone is characterized by relatively fast recharge rate (modern water), small groundwater-table depth $(3.56-8.36 \mathrm{~m})$ and low salinity $(1.25-1.95 \mathrm{~g} / \mathrm{L})$. Stable isotopes show that secondary evaporation takes place during irrigation in oasis. The vegetation characteristics (coverage, richness, evenness and number of plants) are closely related to soil moisture and water-table depth. Groundwater recharge from irrigation in oasis and from river in riparian zone sustains a better ecosystem than that in the desert area, where lateral and vertical groundwater recharge is limited. The more evapotranspirative enrichment may occur in the vegetated and water-rich riparian zone as compared to desert. This study also demonstrates the effectiveness of environmental tracers in studying ecohydrological processes in arid regions.
\end{abstract}

isotope, soil profile, riparian zone, ecosystem, salinity, arid zone hydrology

Citation: Huang T M, Pang Z H, Chen Y N, et al. Groundwater circulation relative to water quality and vegetation in an arid transitional zone linking oasis, desert and river. Chin Sci Bull, 2013, 58: 3088-3097, doi: 10.1007/s11434-013-5948-2

The salinisation of water and ecosystem degradation are two major environmental issues after water shortage in the arid areas [1-3]. Recently, environmental policy has turned to define groundwater not only as a resource but as a living ecosystem [4,5]. In groundwater-dependent ecosystems, groundwater circulation controls the overall water quality and ecosystem dynamics. As groundwater depth, flood events and salt concentration are the key factors controlling the growth of the arbor and shrub [6-8] in the lower reaches of the arid catchments, the variations in water table and quality and their impacts on vegetation growth need to be better understood. One of the disadvantages of high salinity water

*Corresponding author (email: z.pang@mail.iggcas.ac.cn) to vegetation growth is that it prevents vegetation from absorbing moisture and plagues soil fertility $[9,10]$. Plant features, including species richness, species diversity and species composition significantly deteriorate with increasing salinity [11,12]. For example, it has been reported in Australia, that direct adverse biological effects are likely to occur in rivers and wetland ecosystems if salinity rises to around $1 \mathrm{~g} / \mathrm{L}$ [13].

As the current knowledge about the relationship between vegetation growth (e.g. photosynthesis) and stresses of water and salt in arid areas is insufficient [14-16], it has become one of the most active research topics in Ecohydrology $[17,18]$. Understanding the mechanism how groundwater circulation macroscopically control salt and vegetation can 
play a major role in the protection of natural vegetation and in the salt management. In turn, vegetation also plays an important role in hydrological processes, such as redistribution of incident precipitation [19] and consumption of groundwater through transpiration [20]. Vegetation distribution and its effect on hydrological processes [21], water sources of plants [22], ecological water requirement and ecohydrological water-table $[23,24]$ and ecohydrological process simulation [25] are main study focuses in the present research in arid ecohydrology. However, less attention is paid towards the impacts of groundwater circulation on water quality and soil moisture and how it is related to surface vegetation [26,27].

The water-table depth and water quality are mainly controlled by groundwater recharge and circulation in the extremely arid Lower Tarim River (LTR), NW China. A 30-km groundwater transect linking oasis (uncultivated land), de- sert, river and desert again in the LTR offers an opportunity to examine the relationship among groundwater circulation (e.g. water-table depth, groundwater age), soil moisture, water quality and vegetation. It is also a purpose of current study to identify suitable environmental tracers for the ecohydrological processes.

\section{Study area}

The Tarim River Basin (TRB), located in the south of Xinjiang, NW China, is flanked by the Tianshan Mountains to the north and by the Kunlun Mountains to the south (Figure 1). The Aksu River, the Yarkant River and the Hotan River are the three large rivers in the west of the basin, which feed the Tarim River at Aral. The Tarim River starts from Aral and ends at Taitema Lake with a length of $1321 \mathrm{~km}$. There

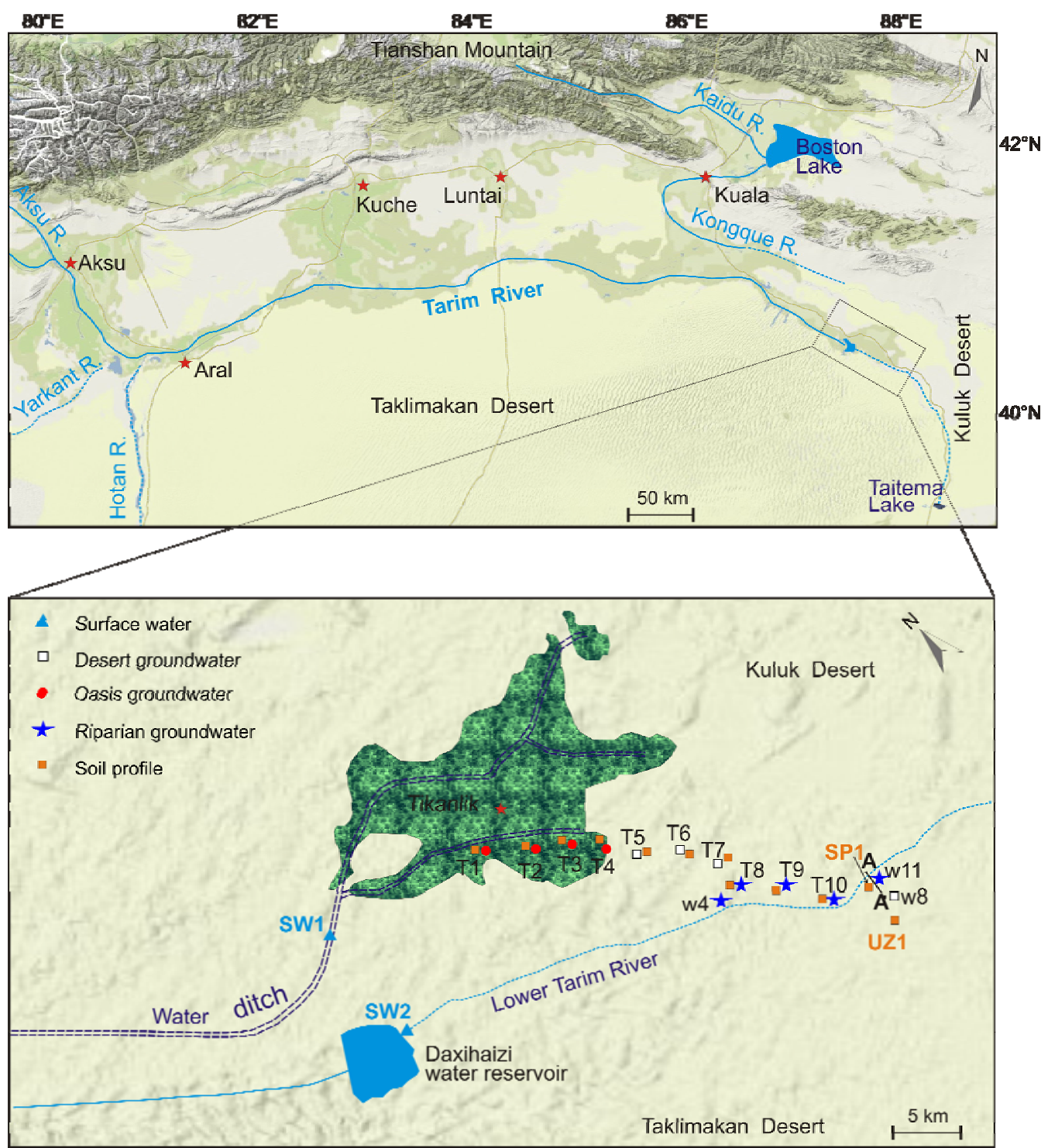

Figure 1 The study area and sampling site. Groundwater sample w4, w8 and w11 and soil profile SP1 were adopted from [34]. 
are two eolian deserts situated on both sides of the LTR, the Taklimakan Desert, the largest desert in China, on the west and the Kuluk Desert on the east.

The LTR is dominated by a typical continental temperate arid climate. According to observations of the Tikanlik meteorological station (Figure 1), the local precipitation ranges from 17.4 to $42.2 \mathrm{~mm} / \mathrm{a}$ and the potential evaporation ranges from 2500 to $3000 \mathrm{~mm} / \mathrm{a}$ [28]. Under the impact of anthropogenic activities, runoff of the three source streams to the Tarim River has decreased gradually in the last 50 years due to extensive oasis agriculture development with increasing water utilization. The runoff has ceased to flow into the $350-\mathrm{km}$-long LTR since the construction of the Daxihaizi water reservoir in 1972, causing severe damages to the riparian forest dominated by Populus euphratica [29]. Since year 2000, several rounds of water diversions from the upper stream and from the neighboring Kaidu-Kongque River have been implemented to alleviate the ecosystem disaster. After the impulsive water diversions, the water tables have risen at differing degrees from the river bed and the composition, types, distribution and growth status of the riparian vegetation and water chemistry have changed correspondingly [30,31]. As the water-table depth suitable for the growth of Populus euphratica is less than 4-5 $\mathrm{m}$ in the LTR, according to the relationship among groundwater quality [31,32] and proline accumulation [33], the zone with the required groundwater depth is restricted, about $200 \mathrm{~m}$ from the river bank, which further narrows down towards downstream [34]. The desert riparian ecological forest formed in the historical period under larger river flow is still diminishing.

The study area is located below the Daxihaizi water reservoir. The Tikanlik oasis is the lowest agriculture area in the TRB. The irrigation water sources are from the upper channel surface water and local groundwater (Figure 1). The main crop is cotton. Zhou et al. [35] investigated the groundwater in the Tikanlik oasis and pointed out that there was evident positive correlation between salinity of surface water and salt content in $0-50 \mathrm{~cm}$ soil and soil salt content was closely related to groundwater depth. In riparian zone, the main arbor is Populus euphratica, the main shrubs are Tamarix ramosissima, Lycium ruthenicum Mur and Halimodendron halodendron, and the main herbs are Phragmites cornmurlis, Poacynum hendersonii, Alhagi sparsifo, Karelinia caspic, Glycarhiza inflate [28,31].

The LTR is located at a flat alluvial plain and the hydrogeological condition is relatively simple (Figure 2). The multi-layered aquifer is dominated by fluvial and lacustrine facies of fine sand and silty fine sand, and locally by eolian sand [36]. The typical porous aquifer can be divided into phreatic and confined ones. The shallow groundwater is closely related to surface water, serving as the main water sources for the riparian vegetation. The phreatic aquifer mainly consists of fine sand and silty fine sand and has a relatively low permeability and poor water yield with the
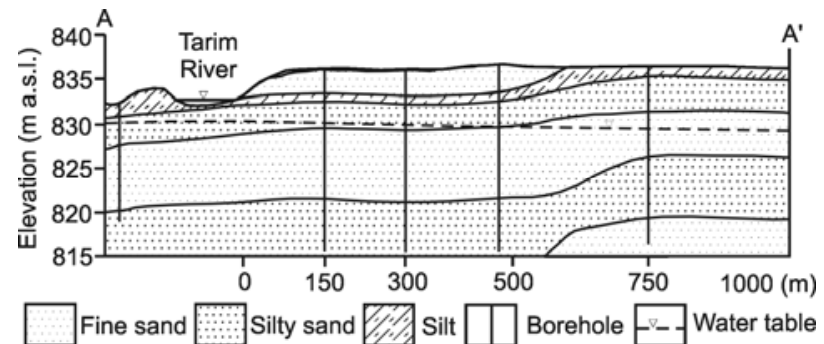

Figure 2 A typical hydrogeological cross section in the Lower Tarim River (LTR) (modified from [36], see Figure 1 for the location).

thickness, hydraulic conductivity and specific discharge of single well of $30-40 \mathrm{~m}, 1.2-4.8 \mathrm{~m} / \mathrm{d}$ and less than 150 $\mathrm{m}^{3} /(\mathrm{d} \mathrm{m})$, respectively. The aquifer is underlain by a clay bed, which extends continuously and horizontally and almost has little hydraulic connection to the confined aquifer underneath [37].

\section{Sampling and analysis}

Groundwater samples were taken from ten wells passing through oasis area (T1-T4, uncultivated land), desert area (T5-T7), and riparian zone (T8-T10) and surface water samples were from water ditch (SW1) and the Daxihaizi water reservoir (SW2) from July to August, 2007. The groundwater samples were taken from the water table of the shallow phreatic aquifer mainly consisting of fine sand and silty fine sand using a $0.5-\mathrm{m}$ plastic pipe. Depth of water table, $\mathrm{pH}$, and the total dissolved solids (TDS) were measured in situ using portable multiparameter Sension $156^{\mathrm{TM}}$ (Hach Company). The $50 \mathrm{~mL}$ water was collected for stable isotopes and was measured in the Institute of Geology and Geophysics, Chinese Academy of Sciences. ${ }^{2} \mathrm{H} / \mathrm{H}$ and ${ }^{18} \mathrm{O} /$ ${ }^{16} \mathrm{O}$ were measured on isotope ratio mass spectrometry (MAT-253 ${ }^{\mathrm{TM}}$ ) by chrome reduction and equilibrium with $\mathrm{CO}_{2}$, respectively. Results are reported as $\delta^{2} \mathrm{H}$ and $\delta^{18} \mathrm{O}$ $\left(\delta=\left(R_{\text {sample }} / R_{\text {standard }}-1\right) \times 1000\right)$ using the Vienna Standard Mean Ocean Water (VSMOW) as standard. The analytical precision is $\pm 1 \%$ o for $\delta^{2} \mathrm{H}$ and $\pm 0.1 \%$ o for $\delta^{18} \mathrm{O}$, respectively. $500 \mathrm{~mL}$ water samples were collected for tritium measurement in the Laboratory of Water Isotopes and Water-Rock Interaction, Institute of Geology and Geophysics, Chinese Academy of Sciences through electrolytic enrichment with a tritium enrichment factor of about 20 and the liquid scintillation counting (Quantulus $1220^{\mathrm{TM}}$ ) method with a detection limit of $0.3 \mathrm{TU}$ (Tritium Unit). Water chemistry was measured using ion chromatography (Dionex-500 ${ }^{\mathrm{TM}}$ ) at Beijing Research Institute of Uranium Geology. Alkalinity was measured on automatic titrator (DMP-785 ${ }^{\mathrm{TM}}$ ). Analytical precision was $3 \%$ of concentration based on reproducibility of samples and standards and detection limit was 0.05 $\mathrm{mg} / \mathrm{L}$. The charge balance error for eight samples with low TDS ranges from $-5 \%$ to $5 \%$ and that for four samples with 
high TDS ranges (10.60-26.50 g/L) from $-10 \%$ to $10 \%$, which may be caused by large dilution ratio. Meanwhile, the study uses two wells data in riparian zone (w4 and w11) and one (w8) in desert area published in our previous paper [34] to constitute a complete profile to study groundwater circulation relative to water quality and vegetation. The results are shown in Table 1.

Eleven soil profiles (T1-T10, UZ1) were also collected (Figure 1). The depth of soil profiles T1 to T10 is $1.7 \mathrm{~m}$ while the depth of soil profile UZ1 is $4 \mathrm{~m}$. The soil samples were obtained using a hollow-stem hand auger with interchangeable $1 \mathrm{~m}$ aluminum rod or a shovel. Bulk soil samples of $\sim 400 \mathrm{~g}$ were collected at intervals of 0.05 to $0.40 \mathrm{~m}$. A minimum of $80 \mathrm{~g}$ of soil sample was weighted in situ immediately after it was taken from profile. Gravimetric moisture content was then determined by drying the soil at $110^{\circ} \mathrm{C}$ for $12 \mathrm{~h}$ in laboratory. The soil samples from profile UZ1 were sealed in polyethylene bags for chloride analysis. Double-deionized water $(40 \mathrm{~mL})$ was added to the ovendried soil sample (40 g). Samples were agitated on a reciprocal shaker table for $8 \mathrm{~h}$. The supernatant was filtered through $0.45 \mu \mathrm{m}$ filters. Chloride was then analyzed by ion chromatography. The chloride concentration of the soil solution $\left(C_{\mathrm{s}}\right)$ is then calculated by dividing the measured concentration $\left(C_{\mathrm{m}}\right)$ by gravimetric moisture content $(\theta)$ and by multiplying the mass ratio of deionized water $\left(M_{\mathrm{w}}\right)$ to oven-dry soil $\left(M_{\mathrm{s}}\right)(1: 1$ in this study):

$$
C_{\mathrm{s}}=\frac{C_{\mathrm{m}}}{\theta} \cdot \frac{M_{\mathrm{w}}}{M_{\mathrm{s}}} .
$$

The vegetation distribution at sites T1-T10 was investi- gated to study the relationship between groundwater circulation and vegetation index. Thirty $50 \mathrm{~m} \times 50 \mathrm{~m}$ plant survey plots (three plots for each site) were sampled. Within each plot, four $25 \mathrm{~m} \times 25 \mathrm{~m}$ subplots were sampled to record characteristics of trees and shrubs, such as number of species, coverage, diameter at breast height, basic diameter, height and width of canopy. Four herbaceous surveys were undertaken in each plot to investigate number of species, coverage, height, and frequency. The following indices were calculated to evaluate the changes in the species diversity, the Margalef index [38], which reflects the richness of species, the Simpson index [39], which represent the evenness of species. The indices are calculated using the following formula:

$$
\begin{gathered}
D_{\text {Margalef }}=\frac{S-1}{\ln N}, \\
D_{\text {Simpson }}=\sum_{i=1}^{S}\left(\frac{N_{i}}{N}\right)^{2},
\end{gathered}
$$

where $N_{i}$ is the number of individuals of species $i, N$ is the total number of individuals in each sampling plot, $S$ is the number of species sampled in a plot. The species density $\left(D_{\text {en }}\right)$ is calculated as

$$
D_{\text {en }}=\frac{N}{A},
$$

where $N$ is the number of plants, $A$ is the area of the plot (50 $\mathrm{m} \times 50 \mathrm{~m}$ in this study). Vegetation coverage is obtained by

\begin{tabular}{|c|c|c|c|c|c|c|c|c|c|c|c|c|c|c|c|}
\hline Sample & Location & $\begin{array}{l}\text { Water depth } \\
\text { (m) }\end{array}$ & $\begin{array}{l}\text { TDS } \\
(\mathrm{g} / \mathrm{L})\end{array}$ & $\mathrm{pH}$ & $\begin{array}{l}\delta^{18} \mathrm{O} \\
(\% o)\end{array}$ & $\begin{array}{l}\delta^{2} \mathrm{H} \\
(\% \circ)\end{array}$ & $\begin{array}{c}{ }^{3} \mathrm{H} \\
(\mathrm{TU})\end{array}$ & $\begin{array}{c}\mathrm{Ca}^{2+} \\
(\mathrm{mg} / \mathrm{L})\end{array}$ & $\begin{array}{c}\mathrm{Mg}^{2+} \\
(\mathrm{mg} / \mathrm{L})\end{array}$ & $\begin{array}{c}\mathrm{Na}^{+} \\
(\mathrm{mg} / \mathrm{L})\end{array}$ & $\begin{array}{c}\mathrm{K}^{+} \\
(\mathrm{mg} / \mathrm{L})\end{array}$ & $\begin{array}{l}\mathrm{HCO}_{3}^{-} \\
(\mathrm{mg} / \mathrm{L})\end{array}$ & $\begin{array}{c}\mathrm{Cl}^{-} \\
(\mathrm{mg} / \mathrm{L})\end{array}$ & $\begin{array}{c}\mathrm{SO}_{4}^{2-} \\
(\mathrm{mg} / \mathrm{L})\end{array}$ & $\begin{array}{c}\mathrm{F}^{-} \\
(\mathrm{mg} / \mathrm{L})\end{array}$ \\
\hline $\mathrm{T} 1$ & oasis & 3.94 & 1.25 & 8.2 & -2.3 & -28.6 & 22.3 & 90 & 79 & 337 & 19 & 115 & 528 & 493 & 1.4 \\
\hline $\mathrm{T} 2$ & oasis & 3.86 & 1.35 & 7.4 & -2.5 & -31.4 & 21.3 & 93 & 87 & 392 & 25 & 119 & 643 & 564 & 1.4 \\
\hline $\mathrm{T} 3$ & oasis & 5.38 & 1.61 & 7.6 & -2.4 & -32.0 & 21.4 & 168 & 91 & 423 & 28 & 129 & 697 & 799 & 1.1 \\
\hline $\mathrm{T} 4$ & oasis & 6.60 & 10.60 & 7.1 & -5.5 & -47.3 & 15.9 & 312 & 395 & 2989 & 65 & 602 & 4697 & 3130 & 2.6 \\
\hline T5 & desert & 8.52 & 16.21 & 7.1 & -5.5 & -48.0 & 0.7 & 723 & 1101 & 4422 & 117 & 388 & 9098 & 5680 & 2.5 \\
\hline T6 & desert & 9.43 & 26.50 & 6.9 & -6.0 & -52.7 & 1.8 & 749 & 1530 & 8498 & 163 & 598 & 15789 & 8087 & 5.4 \\
\hline $\mathrm{T} 7$ & desert & 8.78 & 18.09 & 6.8 & -6.3 & -56.3 & $<0.3$ & 697 & 1204 & 5328 & 85 & 518 & 9995 & 6052 & 3.2 \\
\hline $\mathrm{T} 8$ & riparian zone & 8.36 & 1.95 & 7.4 & -5.5 & -47.3 & 28.8 & 114 & 132 & 534 & 27 & 448 & 767 & 732 & 1.3 \\
\hline T9 & riparian zone & 3.56 & 1.29 & 8.2 & -5.1 & -46.7 & 20.7 & 65 & 78 & 358 & 23 & 106 & 577 & 501 & 1.5 \\
\hline $\mathrm{T} 10$ & riparian zone & 6.33 & 1.28 & 7.9 & -5.6 & -47.9 & 47.3 & 98 & 106 & 312 & 17 & 184 & 538 & 497 & 0.8 \\
\hline w1 $11^{\mathrm{b})}$ & riparian zone & 5.46 & 1.74 & 7.9 & -6.3 & -48.8 & 43.8 & 145 & 142 & 422 & 46 & 321 & 770 & 662 & 1.0 \\
\hline$w 8^{\text {b) }}$ & desert & 6.17 & 15.32 & 7.2 & -6.7 & -53.7 & 1.1 & 571 & 1095 & 4550 & 83 & 754 & 9291 & 5912 & 1.9 \\
\hline SW1 & water ditch & & 0.73 & 8.1 & -8.1 & -56.7 & 19.9 & 67 & 42 & 195 & 12 & 128 & 326 & 254 & 1.1 \\
\hline SW2 & water reservoir & & 0.89 & & & & & 67 & 67 & 239 & 14 & 94 & 353 & 404 & 0.9 \\
\hline
\end{tabular}
direct measurements: the ratio of the vertical shadow against the area of plot. The richness is a measure of plant

Table 1 Water isotopic and chemical compositions for groundwater and surface water ${ }^{\text {a) }}$

a) Sampling locations can be found in Figure 1; b) data source [34]. 
diversity. The evenness is a measure of vegetation density variation in an area being analyzed. The results of soil moisture content of T1-T10 and vegetation investigation have been published [28].

\section{Results and discussion}

\subsection{Groundwater circulation}

Tritium is used to identify groundwater age (modern or premodern). The tritium input sequence of precipitation in the study area was constructed by Huang and Pang [34]. The tritium input in the study area is relatively high. The tritium content for current precipitation was as high as 29.8 TU in 2007 and for surface water it ranges from 18.4 to 28.3 TU [34]. The tritium content for the water ditch (SW1) is 19.9 TU (Table 1). The decayed results show that groundwater with a tritium content less than $10 \mathrm{TU}$ was recharged before 1952, or at least most of it is pre-modern water when mixing with modern water is considered. The tritium contents for shallow groundwaters in the oasis area (T1-T4) and riparian groundwaters (T8-T10, w4 and w11) range from 20.7 to $43.8 \mathrm{TU}$ (Figure 3, Table 1). Beyond the oasis and riparian zone, the tritium contents for desert groundwaters (T5-T7, w8) range from $<0.3$ to $1.8 \mathrm{TU}$, suggesting these groundwaters was recharge before 1952. Long-term retention and evapotranspiration in desert zone makes high salinity, ranging from 15.32 (w8) to $26.50 \mathrm{~g} / \mathrm{L}$ (T6) and relatively high fluoride content, range from 1.9 (w8) to $5.4 \mathrm{mg} / \mathrm{L}$ (T6). Due to the dilution from surface water (TDS $=0.73-$ $0.89 \mathrm{~g} / \mathrm{L} ; \mathrm{F}=0.9-1.1 \mathrm{mg} / \mathrm{L})$, the salinity and fluoride contents for groundwaters from oasis and riparian zone is relatively low, which range from 1.25 (T1) to $1.95 \mathrm{~g} / \mathrm{L}$ (T8), and 0.8 (T10) to $1.5 \mathrm{mg} / \mathrm{L}$ (T9), respectively, except the sample T4 in the transitional zone between oasis and desert (Figure 3). The water-table depth in oasis and riparian zone $(3.56-8.36 \mathrm{~m})$ is shallower than that in desert area $(6.17-$ $9.43 \mathrm{~m})$. Therefore, due to the surface water supplement, the groundwater in oasis and riparian zone is characterized as active recharge, low salinity and shallow water-table depth, compared with groundwater in desert zone.

Stable isotopic compositions for groundwaters in desert and riparian zone are similar, and located below the Global Meteoric Water Line (GMWL) (Figure 4), suggesting evaporation effect during recharge. The riparian groundwaters along the Tarim River [8,34], regardless of modern or premodern, are all enriched in heavy isotopes and are plotted in parallel to the meteoric water line in the $\delta$ - $\delta$ plot, attributed to relatively evaporation during recharge in a rather uniform manner. The phenomenon is commonly observed in dry climate [40-42]. When recharging water enters aquifer and water-table depth is deep and stable, and groundwater persistently evaporates from capillary moisture without direct recharge, there is no isotopic fractionation for remain groundwater. Jankowski and Shekarforoush [43] also commented that the stable isotopes provided no evidence for evaporative concentration in their groundwaters in a dryland. However, shallow groundwaters in oasis are more enriched compared with groundwater in desert and riparian zone with the slope of regression line $(s)$ of $\sim 5$ (Figure 4 ). The oasis groundwaters show $\delta^{18} \mathrm{O}$ values of $-5.5 \%$ to $-2.3 \%$ with an average of $-3.2 \%$ and $\delta^{2} \mathrm{H}$ values of $-47.3 \%$ to $-28.6 \%$ o with an average of $-34.8 \%$. The enriched of heavy isotopes in oasis groundwater indicate that evaporative enrichment occurs during the recharge process (evaporative loss from the soil zone).

\subsection{Water quality}

In the inland arid area, water resources mainly originate from precipitation in mountain area and the runoff represents the total amount of water resources of the whole basin [44]. The minerals contained in the granites and metamorphic rocks are difficult to be dissolved in the alpine areas and the soluble rocks are mainly carbonate [45] in the TRB. The dissolution begins with eroding host rocks with $\mathrm{CO}_{2}$ from soil zone and generally forms low mineralization type water of $\mathrm{HCO}_{3}-\mathrm{Ca}$ in mountainous area with TDS commonly less than $0.5 \mathrm{~g} / \mathrm{L}[34,46]$. However, due to wide distribution of soluble mineral, salt drainage and evapotranspiration, the salinity of river and groundwater increases at the middle and lower reaches [47]. For example, at the Tarim River sections, Fan et al. [48] showed that the average monthly mineralization since 1958 was greater than $1 \mathrm{~g} / \mathrm{L}$ over the entire year except for the wet season (August). The water chemistry type of river and riparian groundwater has become to $\mathrm{Cl}\left(\mathrm{SO}_{4}\right)-\mathrm{Na}(\mathrm{Mg})$ [34,45]. The water types for surface water, desert groundwater, oasis groundwater and riparian groundwater are all $\mathrm{Cl}\left(\mathrm{SO}_{4}\right)-\mathrm{Na}(\mathrm{Mg})$ (Figure 5). The soluble salt in the LTR is mainly evaporite $(\mathrm{NaCl}$, $\left.\mathrm{Ca}_{X} \mathrm{Mg}_{(1-X)} \mathrm{SO}_{4}\right)$ and carbonate minerals $\left(\mathrm{Ca}_{X} \mathrm{Mg}_{(1-X)} \mathrm{CO}_{3}\right)$ due to long-time concentration and accumulation [34]. All samples are located in the transitions between weathering of rocks and evaporation-crystallization in the Gibbs plot [49], far away from the rainfall. The groundwaters in oasis and riparian zone are close to the zone of rock dominance and the desert groundwaters are in the evaporation-crystallization. This feature is similar to other rivers and groundwater in the arid Central Asia [50]. Correlation matrices for TDS and the main ions (Table 2) are used to find relationship between every two of the variables. There are strongly correlations between the TDS and ions ( $r \geqslant 0.92)$ except for $\mathrm{HCO}_{3}(r=0.78)$. All waters are undersaturated with respect to gypsum and supersaturated with respect to calcite and dolomite, suggesting saturation of a relevant salt controls the concentration of the respective ions, e.g. $\mathrm{HCO}_{3}$. Strong correlations also exist between TDS and F ( $r=0.92$ ), which means high $\mathrm{F}$ content in groundwater is mainly attributed to long-term mineral dissolution (e.g. fluorite). Therefore, TDS can be regarded as main water chemistry feature relative to 


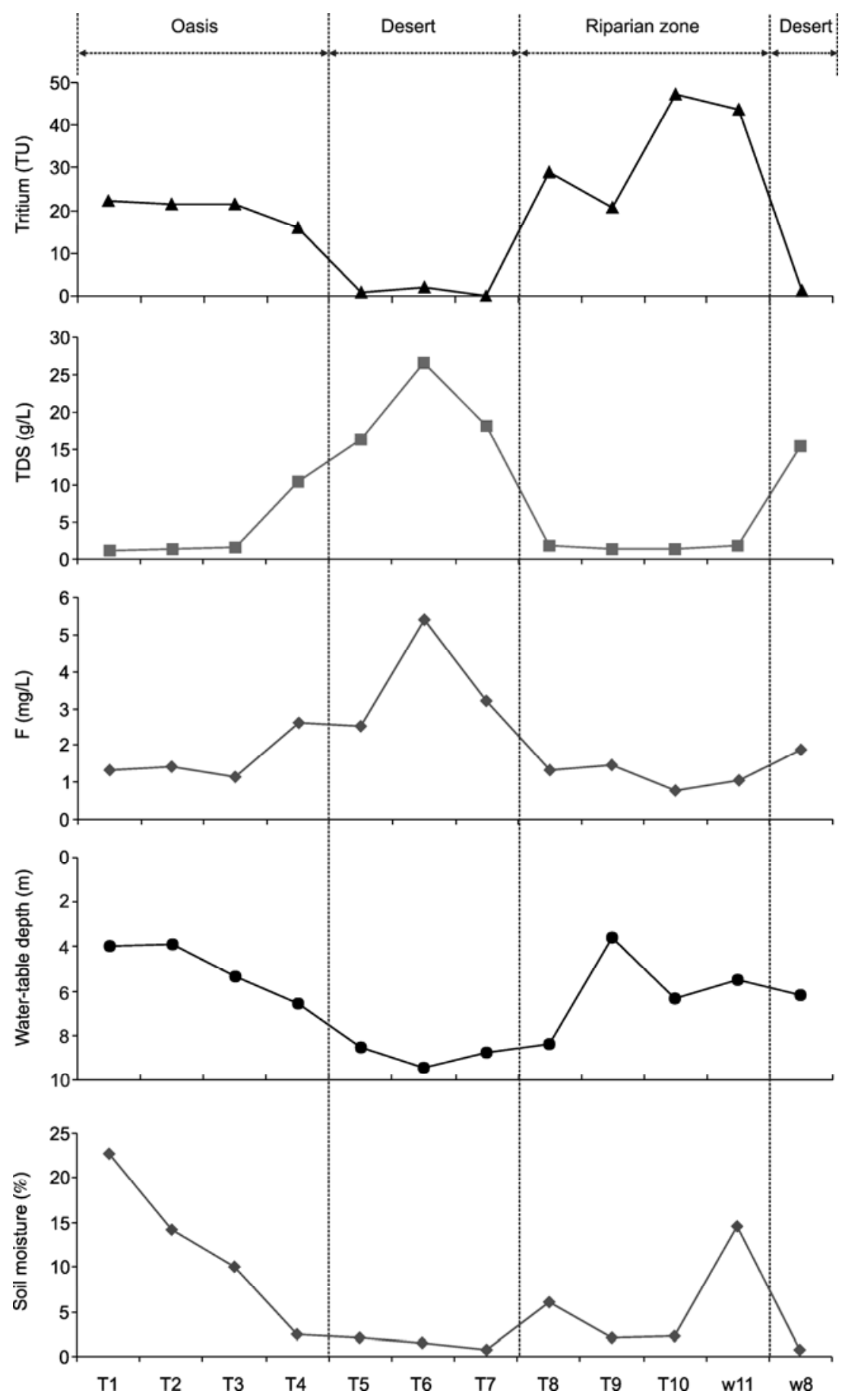

Figure 3 Tritium content, water chemistry (TDS and F), water-table depth and soil moisture content within $1 \mathrm{~m}$ at different land covers.

groundwater circulation.

\subsection{Soil moisture and chloride}

The average of moisture content for soil profile within $1 \mathrm{~m}$ in oasis (T1-T4) and in riparian zone (T8-T10, SP1) is relatively higher than that in desert zone (T5-T7, UZ1) (Figure 3 ). The maximum soil moisture can reach $22.8 \%$ in oasis (T1) and $24.5 \%$ in riparian zone (SP1). The average soil moisture in desert zone (T5-T7, UZ1) is $1.3 \%$. Lateral recharge from irrigation water in oasis area and the diverted water in riparian zone causes relatively high water table and high soil moisture content.

In the riparian zone, near surface soil moisture is low (2.16\%) for SP1, but generally increases with depth until coming into contact with silt layer (Figure 6), with the depth of $0.55 \mathrm{~m}$ for SP1. Below the silt layer, the moisture content decreases rapidly before reaching the water table. It can be 


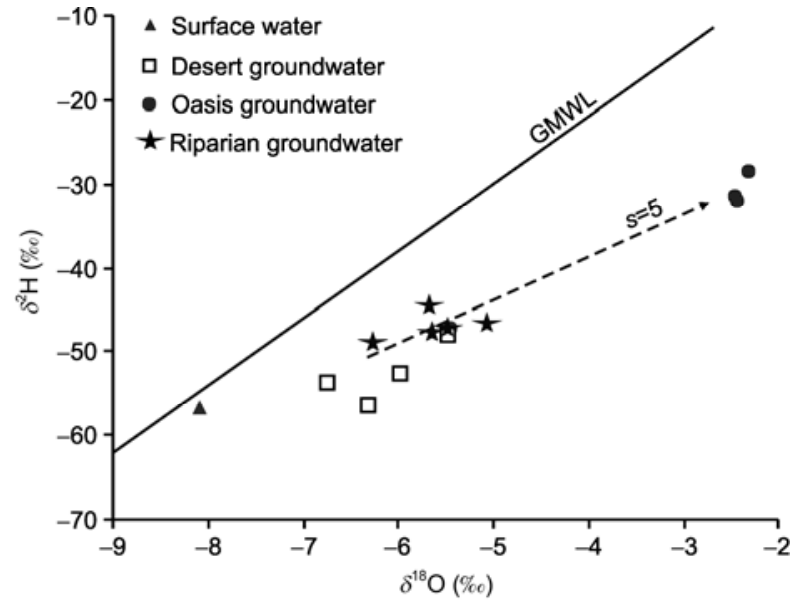

Figure 4 Stable isotopic compositions for surface water and groundwater.

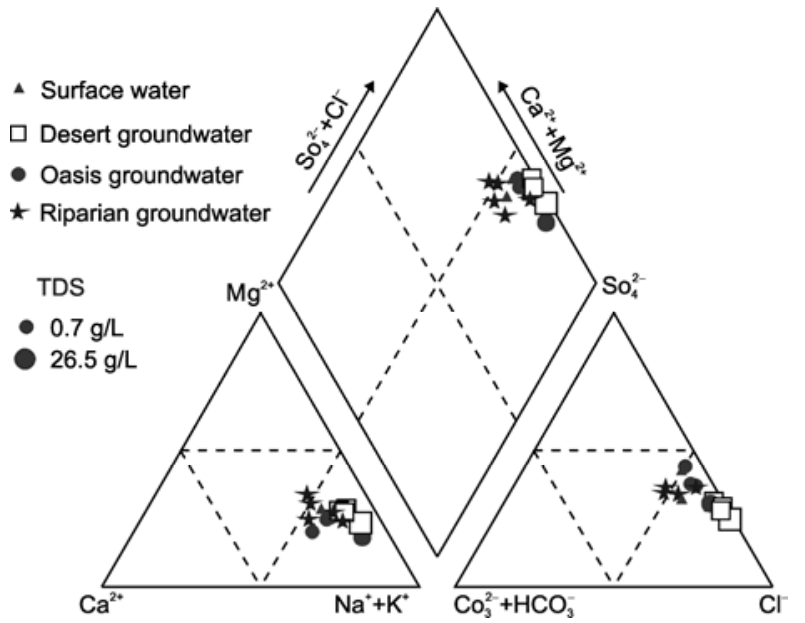

Figure 5 Piper plot for surface water and groundwater.

Table 2 Correlation matrices for showing marked correlation at a signification level of $0.05(n=15)$

\begin{tabular}{|c|c|c|c|c|c|c|c|c|c|}
\hline & TDS & $\mathrm{Ca}^{2+}$ & $\mathrm{Mg}^{2+}$ & $\mathrm{Na}^{+}$ & $\mathrm{K}^{+}$ & $\mathrm{HCO}_{3}^{-}$ & $\mathrm{Cl}^{-}$ & $\mathrm{SO}_{4}^{2-}$ & $\mathrm{F}^{-}$ \\
\hline TDS & 1 & & & & & & & & \\
\hline $\mathrm{Ca}^{2+}$ & 0.97 & 1 & & & & & & & \\
\hline $\mathrm{Mg}^{2+}$ & 0.98 & 0.98 & 1 & & & & & & \\
\hline $\mathrm{Na}^{+}$ & 1.00 & 0.95 & 0.98 & 1 & & & & & \\
\hline $\mathrm{K}^{+}$ & 0.97 & 0.94 & 0.95 & 0.97 & 1 & & & & \\
\hline $\mathrm{Cl}^{-}$ & 1.00 & 0.96 & 0.99 & 1.00 & 0.97 & 0.76 & 1 & & \\
\hline $\mathrm{SO}_{4}^{2-}$ & 0.99 & 0.98 & 0.99 & 0.99 & 0.96 & 0.79 & 0.99 & 1 & \\
\hline $\mathrm{F}^{-}$ & 0.92 & 0.83 & 0.86 & 0.94 & 0.91 & 0.64 & 0.92 & 0.88 & 1 \\
\hline
\end{tabular}

concluded that the soil type controls its moisture content for the profile SP1. However, due to the very limited recharge (vertical or lateral) in the desert, the soil moisture is very low ranging from $0.17 \%$ to $1.17 \%$ with an average of $0.39 \%$ (Figure 6). In the situation, the soil particle composition of silty sand and silt play an unimportant role in soil moisture distribution. The soil moisture is more depleted compared with that in the Badain Jaran Desert $(1 \%-3 \%$, [51,52]) and in the Tengger Desert (1\%-5\%, [41]), where precipitation is about 90 and $150 \mathrm{~mm} / \mathrm{a}$, respectively. The average soil moisture content within $1 \mathrm{~m}$ is $0.75 \%$ for UZ1, similar to $\sim 0.8 \%$ in profile around $\mathrm{T} 7$.

Since chloride is a conservative tracer in water cycle process that can only precipitate in very high concentration and is a good tracer to check the salt content in the unsaturated zone. The chloride concentrations in capillary samples for SP1 is $487 \mathrm{mg} / \mathrm{L}$, less than that in groundwater samples, which ranges from 665 to $770 \mathrm{mg} / \mathrm{L}$. There is an increasing trend in chloride concentration from the bottom to the top of the profile SP1. Persistently removing the moisture near surface by evapotranspiration contributes the accumulation of solutes. Above $0.75 \mathrm{~m}$, the chloride content in dry soil is
$318-709 \mathrm{mg} / \mathrm{kg}$. The chloride content of SP1 ranges from 151 to $862 \mathrm{mg} / \mathrm{kg}$ above $2 \mathrm{~m}$, and is more enriched than that of UZ1 for the whole depth. This may be contributed by more evapotranspirative enrichment occurs in the vegetated and water-rich riparian zone.

\subsection{Vegetation index and conceptual model}

In the extremely arid areas, biological activity is limited and ecosystems are small and unstable, and change in the water table directly influences the development and composition of vegetation. Figure 7 shows the vegetation index and soil moisture content at the section linking oasis, desert and riparian zone. The vegetation coverage ranges from 0.30 to 1.00 in oasis and from 0.24 to 0.64 in riparian zone, respectively, significantly higher than that in desert zone $(0.04-$ $0.15)$. Correspondingly, the other vegetation indexes, such as richness, number of plants and evenness have similar distribution characteristics linking oasis, desert and riparian zone. Therefore, the shallow water-table depth controls the soil moisture and then controls the development of vegetation distributions. The investigation shows that distribution 


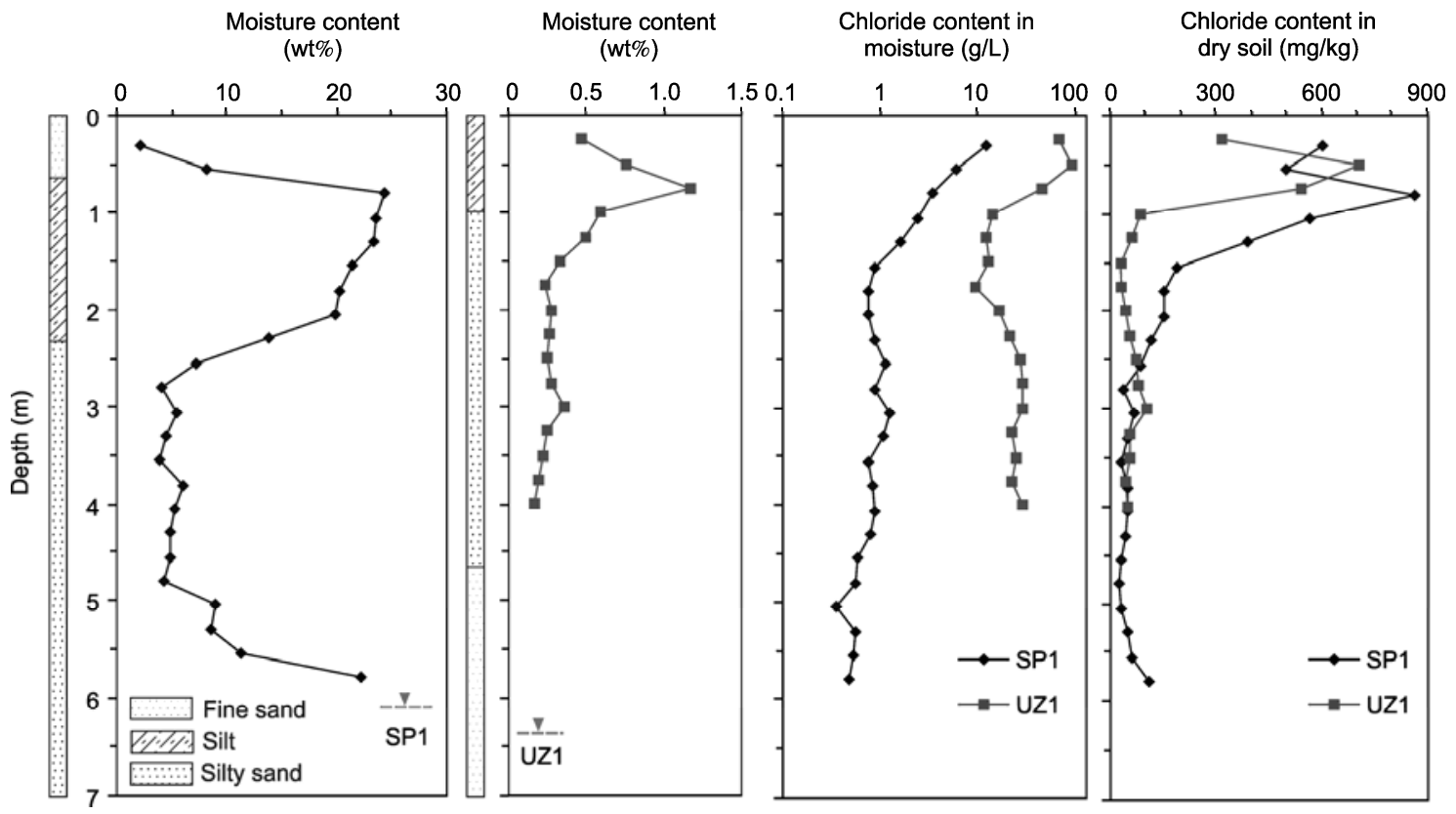

Figure 6 Moisture and chloride content for soil profile. The gray dot lines indicate water table depth. The SP1 is adopted from [34]. UZ1 is located in the desert area while SP1 in the riparian zone.

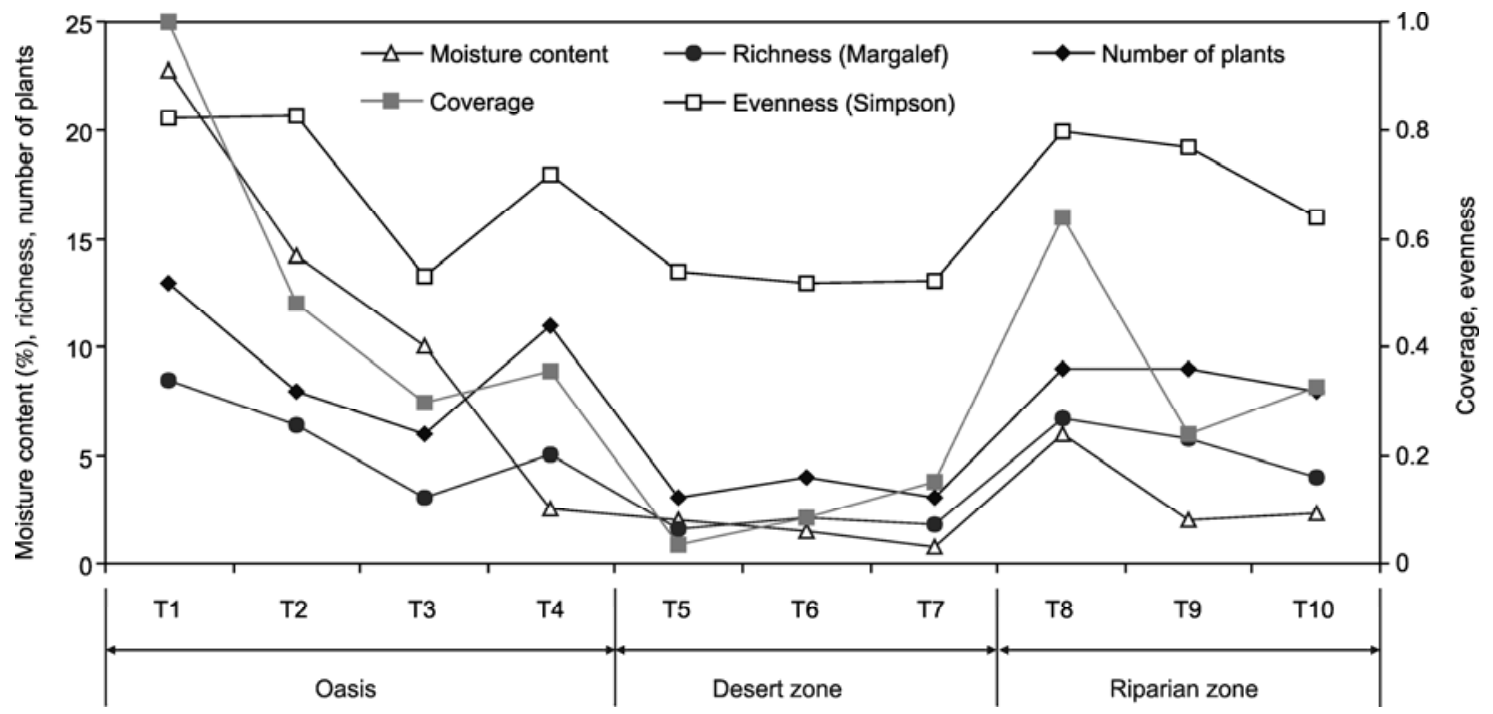

Figure 7 Vegetation index and soil moisture within $1 \mathrm{~m}$ around the sampling sites.

of natural vegetation is closely related to soil moisture and water-table depth.

The 30-km section linking oasis, desert zone, riparian zone and desert zone again shows that the groundwater in desert is premodern water, where water-table depth is deep, soil moisture content is low, salinity is high and vegetation coverage is low due to the limited recharge (Figure 8). Meanwhile in oasis and riparian zone, due to water recharge from irrigation and river, the water-table depth is relatively shallow and soil moisture is high. The vegetation distribution characteristics are closely related to water-table depth and soil moisture content.

\section{Conclusions}

A combined use of stable isotopes, tritium and water chemistry in the lower reaches of the arid Tarim River provides insights into groundwater circulation. Sampling and analysis of a $30-\mathrm{km}$ transect linking oasis, desert and river reveals the relationship between groundwater circulation (groundwater age, water depth, soil moisture) and natural vegetation distribution characteristics. The vegetation coverage is closely related to water-table depth and soil moisture. Due to evaporation during irrigation in oasis, groundwater samples show signals of secondary evaporation in stable isotopic 


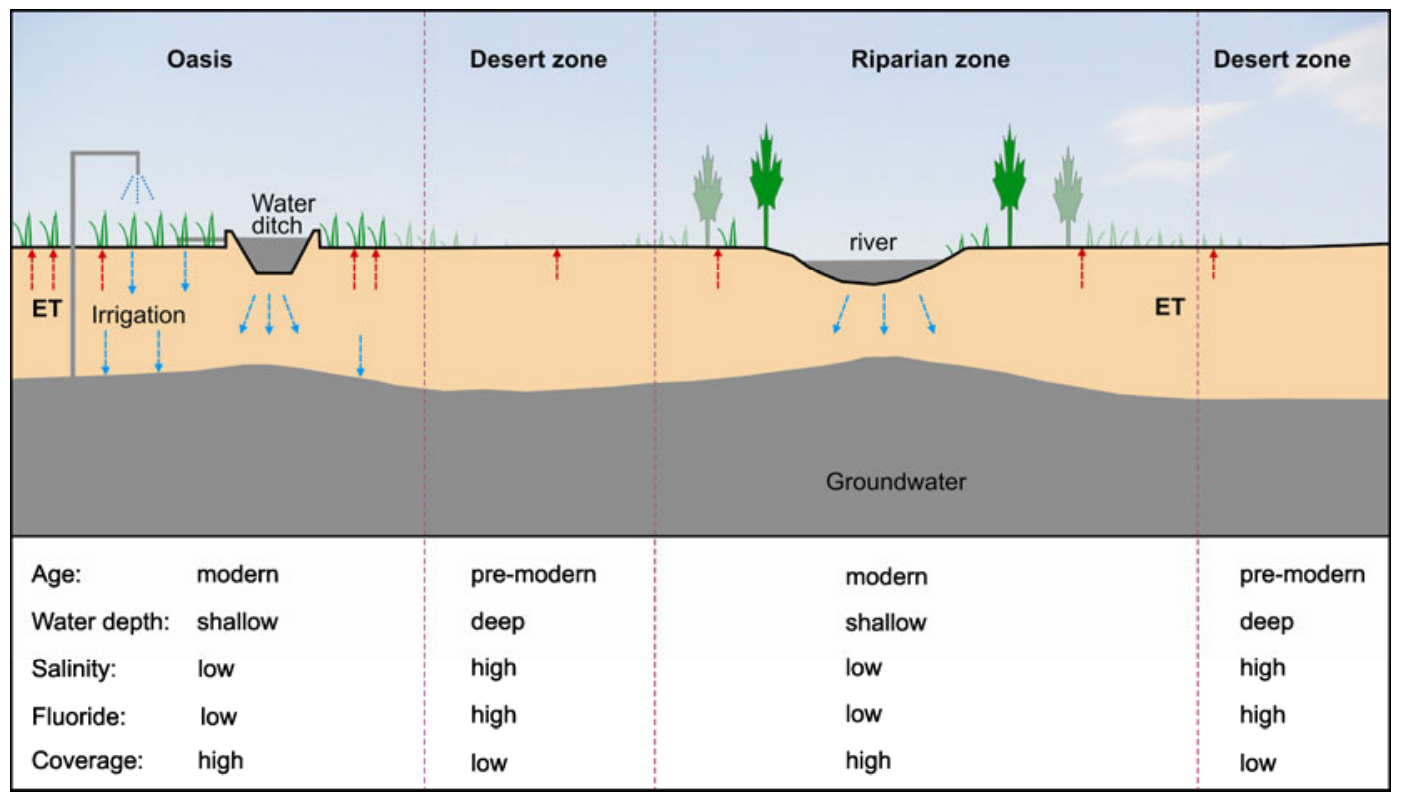

Figure 8 A conceptual model for groundwater circulation and vegetation distribution.

composition. Groundwater in oasis and riparian zone is charactered by modern age, shallow depth, and low salinity. The study on the relationship between vegetation coverage and groundwater circulation is of great importance for recovering degraded ecosystem and managing groundwater dependent ecosystems in the (semi)arid areas, such as other arid areas in NW China [53], southwestern United States [54] and Australia [55,56].

This work was supported by the National Natural Science Foundation of China (41202183, 40872162 and 40672171) and the China Postdoctoral Science Foundation Funded Project (2012T50136 and 20110490581). The authors thank Drs. Zhou Xiaoming, Zhu Chenggang and Duan Zhongfeng for their assistance in the field work and Dr. Xu Bing for tritium analyses. Thanks are also due to the editor and anonymous reviewers, whose detailed comments helped improving the final manuscript.

1 Steube C, Richter S, Griebler C. First attempts towards an integrative concept for the ecological assessment of groundwater ecosystems. Hydrogeol J, 2009, 17: 23-35

2 Tamea S, Laio F, Ridolfi L, et al. Ecohydrology of groundwaterdependent ecosystems: 2. stochastic soil moisture dynamics. Water Resour Res, 2009, 45: W05420

3 Gaye C B. Isotope techniques for monitoring groundwater salinization. Hydrogeol J, 2001, 9: 217-218

4 Griebler C, Stein H, Kellermann C, et al. Ecological assessment of groundwater ecosystems-Vision or illusion? Ecol Eng, 2010, 36: $1174-1190$

5 Williams W D. Salinisation: A major threat to water resources in the arid and semiarid regions of the world. Lake Reserv Res Manage, 1999, 4: 85-91

6 Williams D G, Scott R L, Huxman T E, et al. Sensitivity of riparian ecosystems in arid and semiarid environments to moisture pulses. Hydrol Process, 2006, 20: 3191-3205

7 Thevs N, Zerbe S, Schnittler M, et al. Structure, reproduction and flood-induced dynamics of riparian Tugai forests at the Tarim River in Xinjiang, NW China. Forestry, 2008, 81: 45-57

8 Pang Z H, Huang T M, Chen Y N. Diminished groundwater recharge and circulation relative to degrading riparian vegetation in the middle Tarim River, Xinjiang, Western China. Hydrol Process, 2010, 24: $147-159$

9 He X C, Shao D G, Liu W Y, et al. Review of the researches on utilization of farmland drainage as resources (in Chinese). T CSAE, 2006, 22: 176-179

10 Manchanda G, Garg N. Salinity and its effects on the functional biology of legumes. Acta Physiol Plant, 2008, 30: 595-618

11 Lymbery A J, Doup R G, Pettit N E. Effects of salinisation on riparian plant communities in experimental catchments on the Collie River, Western Australia. Aust J Bot, 2003, 51: 667-672

12 Rietz D N, Haynes R J. Effects of irrigation-induced salinity and sodicity on soil microbial activity. Soil Biol Biochem, 2003, 35: 845854

13 Hart B T, Bailey P, Edwards R, et al. A review of the salt sensitivity of the Australian fresh-water biota. Hydrobiologia, 1991, 210: 105144

14 Hatton T, Evans R. Dependence of Ecosystems on Groundwater and Its Significance to Australia. Canberra: Land and Water Resources Research and Development Corporation Press, 1998

15 Chaves M M, Flexas J, Pinheiro C. Photosynthesis under drought and salt stress: Regulation mechanisms from whole plant to cell. Ann Bot, 2009, 103: 551-560

16 Cheng D H, Wang W K, Chen X H, et al. A model for evaluating the influence of water and salt on vegetation in a semiarid desert region, northern China. Environ Earth Sci, 2011, 64: 337-346

17 Newman B D, Wilcox B P, Archer S R. Ecohydrology of water-limited environments: A scientific vision. Water Resour Res, 2006, 42: 1-15

18 Jin X M, Wan L, Zhang Y K, et al. A study of the relationship between vegetation growth and groundwater in the Yinchuan Plain (in Chinese). Earth Sci Front, 2007, 14: 197-203

19 Li X Y, Yang Z P, Li Y T, et al. Connecting ecohydrology and hydropedology in desert shrubs: Stemflow as a source of preferential flow in soils. Hydrol Earth Syst Sci, 2009, 13: 1133-1144

20 Wood P J, Hannah D M, Sadler J P. Hydroecology and Ecohydrology: Past, Present and Future. Chichester: John Wiley \& Sons Ltd, 2007. $1-436$

21 Zhao W Z, Liu B, Zhang Z H. Water requirements of maize in the middle Heihe River basin, China. Agr Water Manage, 2010, 97: 215223

22 Zhao J L, Xiao H L, Chen G D, et al. A preliminary study of water sources of riparian plants in the lower reaches of the Heihe basin (in 
Chinese). Acta Geosci Sin, 2008, 29: 709-718

23 Wang G X, Cheng G D. Water demand of eco-system and estimate method in arid inland river basins (in Chinese). J Desert Res, 2002, 22: $129-134$

24 Chen Y N, Hao X M, Li W H, et al. An analysis of the ecological security and ecological water requirements in the inland river of arid region (in Chinese). Adv Earth Sci, 2008, 23: 732-738

25 Yan D H, Wang H, Yan S Y, et al. Some opinions on the ecohydrological processes simulation and regulation in arid basins (in Chinese). Adv Earth Sci, 2008, 23: 773-778

26 Eamus D, Froend R, Loomes R, et al. A functional methodology for determining the groundwater regime needed to maintain the health of groundwater-dependent vegetation. Aust J Bot, 2006, 54: 97-114

27 Zhu J T, Yu J J, Wang P, et al. Interpreting the groundwater attributes influencing the distribution patterns of groundwater-dependent vegetation in northwestern China. Ecohydrology, 2012, 5: 628-636

28 Zheng T, Li W H, Li J G, et al. Characters of community diversity in the oasis-desert transition zone in lower reaches of Tarim River (in Chinese). J Desert Res, 2009, 29: 241-247

29 Song Y D, Fan Z L, Lei Z D. Research on Water Resources and Ecology of Tarim River, China (in Chinese). Urumqi: Xinjiang People's Press, 2000. 1-255

30 Hou P, Beeton R J, Carter S, et al. Response to environmental flows in the lower Tarim River, Xinjiang, China: Ground water. J Environ Manage, 2007, 83: 371-382

31 Chen Y N, Pang Z H, Chen Y P, et al. Response of riparian vegetation to water-table changes in the lower reaches of Tarim River, Xinjiang, China. Hydrogeol J, 2008, 16: 1371-1379

$32 \mathrm{Xu} \mathrm{H} \mathrm{L,} \mathrm{Ye} \mathrm{M,} \mathrm{Song} \mathrm{Y} \mathrm{D,} \mathrm{et} \mathrm{al.} \mathrm{The} \mathrm{natural} \mathrm{vegetation} \mathrm{responses} \mathrm{to}$ the groundwater change resulting from ecological water conveyances to the Lower Tarim River. Environ Monit Assess, 2007, 131: 37-48

33 Chen Y N, Chen Y P, Li W H, et al. Response of the accumulation of proline in the bodies of Populus euphratica to the change of ground water level at the lower reaches of Tarim River. Chin Sci Bull, 2003, 48: 1995-1999

34 Huang T M, Pang Z H. Changes in groundwater induced by water diversion in the Lower Tarim River, Xinjiang, NW China: Evidence from environmental isotopes and water chemistry. J Hydrol, 2010, 387: 187-201

35 Zhou H H, Chen Y N, Li W H. Effect of oasis hydrological processes on soil salinization of Tikanlik oasis in the Lower Tarim River (in Chinese). Acta Geogr Sin, 2008, 63: 714-724

36 Deng M. Theory and Practice of Water Management in the Tarim River, China (in Chinese). Beijing: Science Press, 2009. 1-526

37 Alim T, Xu W. Study on the groundwater movement in the vicinities along the river channel of stream water transportation to the lower reaches of Tarim River, Xinjiang (in Chinese). Arid Land Geogr, 2003, 26: 129-135

38 Margalef R. Information theory in ecology. Gen Syst, 1958, 3: 36-71

39 Simpson E H. Measurement of diversity. Nature, 1949, 163: 668

40 Chapman J B, Lewis B, Litus G. Chemical and isotopic evaluation of water sources to the fens of South Park, Colorado. Environ Geol,
2008, 43: 533-545

41 Ma J Z, Ding Z Y, Edmunds W M, et al. Limits to recharge of groundwater from Tibetan Plateau to the Gobi desert, implications for water management in the Mountain front. J Hydrol, 2009, 364: 128-141

42 Huang T M, Pang Z H, Edmunds W M. Soil profile evolution following land-use change: Implications for groundwater quantity and quality. Hydrol Process, 2013, 27: 1238-1252

43 Jankowski J, Shekarforoush S. Sustainable management of groundwaters in dryland salinity affected Spring Creek catchment, New South Wales, Australia. In: Sililo O, ed. Proceeding of XXX IAH Congress on Groundwater: Past Achievements and Future Challenges. Cape Town: A. A. Balkema Publishers, 2000. 521-526

44 Li W P, Hao A B, Liu Z, et al. Perspective Areas for Groundwater Development in Tarim Basin (in Chinese). Beijing: Geological Publishing House, 2000. 1-149

45 Zhu B Q, Yang X P. The ion chemistry of surface and ground waters in the Taklimakan Desert of Tarim Basin, western China. Chin Sci Bull, 2007, 52: 2123-2129

46 Zhang J, Takahashi K, Wushiki H, et al. Water geochemistry of the rivers around the Taklimakan Desert (NW China): Crustal weathering and evaporation process in arid land. Chem Geol, 1995, 119: 225-237

47 Huang $\mathrm{T} \mathrm{M}$, Pang $\mathrm{Z} \mathrm{H}$. The role of deuterium excess in determining the water salinisation mechanism: A case study of the arid Tarim River Basin, NW China. Appl Geochem, 2012, 27: 2382-2388

48 Fan Z L, Ma Y, Zhang H, et al. Salinization and improvement ways of water quality of Tarim River, Xinjiang, China (in Chinese). Adv Water Sci, 2002, 13: 719-725

49 Gibbs R J. Mechanisms controlling world water chemistry. Science, 1970, 170: 1088-1090

50 Zhu B Q, Yang X P, Rioual P, et al. Hydrogeochemistry of three watersheds (the Erlqis, Zhungarer and Yili) in northern Xinjiang, NW China. Appl Geochem, 2011, 26: 1535-1548

51 Ma J Z, Edmunds W M. Groundwater and lake evolution in the Badain Jaran Desert ecosystem, Inner Mongolia. Hydrogeol J, 2006, 14 : 1231-1243

52 Gates J B, Edmunds W M, Ma J Z, et al. Estimating groundwater recharge in a cold desert environment in northern China using chloride. Hydrogeol J, 2008, 16: 893-910

53 Zhang Y C, Yu J J, Wang P, et al. Vegetation responses to integrated water management in the Ejina basin, northwest China. Hydrol Process, 2011, 25, 3448-3461

54 Stromberg J C, Beauchamp V B, Dixon M D, et al. Importance of low-flow and high-flow characteristics to restoration of riparian vegetation along rivers in arid southwestern United States. Freshwater Biol, 2007, 52: 651-679

55 Eamus D, Froend R, Loomes R, et al. A functional methodology for determining the groundwater regime needed to maintain the health of groundwater-dependent vegetation. Aust J Bot, 2006, 54: 97-114

56 Tomlinson M, Boulton A J. Ecology and management of subsurface groundwater dependent ecosystems in Australia-A review. Mar Freshwater Res, 2010, 61: 936-949

Open Access This article is distributed under the terms of the Creative Commons Attribution License which permits any use, distribution, and reproduction in any medium, provided the original author(s) and source are credited. 